\title{
Agricultural Polices To Enhance The Development Of Fruit And Vegetable Subsectors In Uzbekistan
}

\author{
Shavkat Hasanov \\ Department of Agricultural Economics and Marketing, \\ Samarkand Agricultural Institute (University), Uzbekistan
}

doi: 10.19044/esj.2016.v12n13p479 URL:http://dx.doi.org/10.19044/esj.2016.v12n13p479

\begin{abstract}
Uzbekistan's fertile land is highly suitable for growing fruits and vegetables, making it one of the main producers among the Commonwealth of Independent States (CIS) countries. The location of Uzbekistan also provides a ready access to the growing Central Asian and Russian consumer markets. Since its independence, the country implemented a number of agricultural policies targeted at the development of agricultural sector, comprising institutional and structural reforms. The aim of the study is to review the agricultural sector of Uzbekistan and to identify the major constraints to the development of fruits and vegetables subsectors. In doing this, the objective is to put forward policy recommendations for the development of these sector. Fruit and vegetables supply chain potential of the Samarkand region is the key topic of investigation. The recent reforms have provided opportunities for liberalization in agricultural production, especially for the fruit and vegetable subsectors. Yet, modernization of agriculture per se and of the marketing system in Uzbekistan remain areas requiring continued attention for the overall sectorial development. Based on the analysis, the paper provides policy suggestions for implementation. Specific recommendations are outlined pertaining to the identified key constraints; namely, pertaining to agricultural production and productivity, quality of land resources, irrigation, reforms, R\&D, and agricultural marketing.
\end{abstract}

Keywords: Agricultural Marketing, Agro-Processing, Fruits and Vegetables, postharvest management, value addition, innovations, Uzbekistan

\section{Introduction}

Agriculture plays a vital role in rural income, employment, livelihoods, food security. Agriculture has traditionally been a strong and relatively stable contributor to Uzbekistan's economy. Between 2000 and 2013, the sector expanded at an average annual rate of ca. 7\%. Despite this 
growth rate, the sector's share in GDP declined from 32\% to $17.6 \%$ between 1995 and $2015^{1}$, due to other sectors' expansion outpacing agriculture. Approximately $60 \%$ of the gross agricultural value comes from the crop production, while the rest is contributed by the livestock sector. Cotton is the most important crop, where Uzbekistan ranks fifth among the 90 cottongrowing countries, contributes ca. $6 \%$ of the global cotton production, and is (after the U.S.) the second largest cotton exporter in the world (Djanibekov et al., 2010). Following the independence of Uzbekistan in 1991, cotton production remained linked to the overreaching goal of increasing national export earnings, which were cemented in a cotton procurement policy (Guadagni et al., 2005). Since independence, and because of the food selfsufficiency policy adopted by the Government of Uzbekistan, wheat became the country's second strategic crop. Both cotton and wheat cover approximately $75.6 \%$ of the cultivated area, whereas the rest is cultivated with fruit and vegetables, potatoes, tobacco and fodder crops. Uzbekistan continues to be one of the major suppliers of fresh and processed fruit and vegetables in the region.

With regard to food consumption, significant changes have been observed over the years. In the 1990s, the country imported over $82 \%$ of its total grain consumption, $50 \%$ of meat and meat products, $60 \%$ of dairy products, $50 \%$ of potatoes, $100 \%$ of sugar and powdered milk and baby food (Kim \& Hasanov, 2013). As of today, Uzbekistan has achieved selfsufficiency for almost all basic food products due to the quick progress of domestic production (with the exception of sugar). Uzbekistan produces a range of high quality agricultural products, from the strategic commodities such as cotton and wheat to higher value horticultural products such as cherries, pomegranates, and other fruit and vegetables. High quality and a wide range of products, easy access to the growing Central Asian and Russian consumer markets, a vast pool of skilled and inexpensive workforce and a wide set of Government incentives - all boost the attractiveness of this sector.

In the past, the agricultural policies were centered at the strategically important crops cotton and wheat, whereas fruit and vegetables received less policy attention. As of recently, agricultural policy in Uzbekistan started putting more weight on the diversification of agricultural production shifting focus towards high-value agricultural commodities, including fruit and vegetables. The government, therefore, has recently issued several legislative acts to increase the production of fruit and vegetables throughout the country. All the same, still $30-40 \%$ of fruit and vegetables continue to be lost or abandoned after leaving the farm gate.

1 StatUz-Base on An Outlook of The State Statistical Committee of Uzbekistan, 2015 
Uzbekistan adopted a number of laws to encourage agricultural growth and rural development (Table 1).

Table 1: Chronology of main laws related to the expansion of fruit and vegetable production in Uzbekistan

\begin{tabular}{|c|c|c|}
\hline Year & Law & Main focus \\
\hline 11.01 .2006 & $\begin{array}{l}\text { Decree of the President "On organizational } \\
\text { measures towards reforms in fruits, vegetables and } \\
\text { grape production sector" }\end{array}$ & $\begin{array}{l}\text { Transformation of agri } \\
\text { cooperatives to individual } \\
\text { farms, establishment of agro- } \\
\text { industrial companies, } \\
\text { enhancement of sectoral } \\
\text { administration }\end{array}$ \\
\hline 10.03 .2006 & $\begin{array}{l}\text { Resolution of the Cabinet of Ministers of the } \\
\text { Republic of Uzbekistan "On adoption of the } \\
\text { resolution on procedure of establishment of } \\
\text { agricultural companies and organization of their } \\
\text { activities in fruits, vegetables and grape production } \\
\text { sectors" }\end{array}$ & $\begin{array}{l}\text { Establishment of agricultural } \\
\text { companies, elaboration of } \\
\text { contract template between } \\
\text { producers and processors }\end{array}$ \\
\hline 20.08 .2007 & $\begin{array}{l}\text { Resolution of the Cabinet of Ministers "On } \\
\text { adoption of the procedure of the preferential } \\
\text { crediting schemes and leasing services for } \\
\text { purchasing of mini-technologies and compact } \\
\text { equipment by farms and other small business } \\
\text { enterprises engaged in processing of fruits, } \\
\text { vegetables and livestock products” }\end{array}$ & $\begin{array}{l}\text { Preferential loans and } \\
\text { enhancement of leasing } \\
\text { system for mini-technologies } \\
\text { and equipment }\end{array}$ \\
\hline 20.10 .2008 & $\begin{array}{l}\text { Decree of the President "On optimization of farn } \\
\text { plots and measurements towards increasing food } \\
\text { production" }\end{array}$ & $\begin{array}{l}\text { Sustainable production of } \\
\text { food products, farm } \\
\text { restructuring }\end{array}$ \\
\hline 31.10 .2011 & $\begin{array}{l}\text { Decree of the President "On measures of } \\
\text { development and enhancement of management } \\
\text { system in national food-industry sector for 2012- } \\
2015 \text { ” }\end{array}$ & $\begin{array}{l}\text { Food industry development, } \\
\text { foreign investment to } \\
\text { agricultural }\end{array}$ \\
\hline 23.08 .2012 & $\begin{array}{l}\text { Resolution of the Cabinet of Ministries "On } \\
\text { additional measures towards deepening processing } \\
\text { of agricultural commodities, increasing volume of } \\
\text { production and expand assortment of food } \\
\text { products for 2012-2015” }\end{array}$ & $\begin{array}{l}\text { Increase of volume of food } \\
\text { products, crop diversification }\end{array}$ \\
\hline 12.04 .2016 & $\begin{array}{l}\text { Decree of the President "On measures towards } \\
\text { enhancing procurement system of fruits- } \\
\text { vegetables, potato and melon products" }\end{array}$ & $\begin{array}{l}\text { Increase volume of products } \\
\text { and exports, enhance } \\
\text { processing and storage } \\
\text { infrastructure }\end{array}$ \\
\hline
\end{tabular}

Source: Author's compilation based on Lex.uz.

The processing sector in Uzbekistan, however, faces various challenges. Among them are the following ones:

(a) most fruits and vegetables producers are small-scale farms and have low levels of mechanization. The recent study by Petrick and Djanibekov (2016) shows that the these farms are in a disadvantage compared to larger farms involved in cotton and wheat production. 
Particularly, smaller farms lack access to markets and have insufficient collateral to obtain credits.

(b) The distribution chain is developing, but still needs substantial investment (Larson et al., 2015);

(c) Quality standards are not uniform across products and producers (Larson et al., 2015);

(d) Moreover, much of the country's agricultural output goes unprocessed. In harvest season, a lack of adequate packaging and storage facilities causes a large volume of products to directly release to markets, creating surplus that triggers price declines. Using the 2002-2010 weekly data collected from local markets in another region of Uzbekistan Mori-Clement et al. (2015) show that the prices of apples, onions, potatoes, tomatoes, carrots are determined locally and clearly follow seasonal fluctuations (sawtooth pattern) reaching a minimum during the harvest season and a maximum in the off-season. In the off-season, commodities such as apples are imported from China and Iran, with significantly higher prices than domestically produced during the season.

The establishment of an agro-food cluster serves to ensure that sustainable agricultural development is realized and marketing systems are developed. The core principles underlying the clustering concept are networking and creation of value-added products based on research and development (R\&D). A paradigm shifts from processing intensive production systems by individual enterprises targeting domestic markets to value-adding production. Networks of processing-aimed producers focusing on exportpromotion can benefit from the implementation of agri-cluster approach as it contributes to enhancing the competitiveness of Uzbekistan's agricultural and agro-food sector. Thereby, clustering ultimately helps to achieve sustainable growth of the agricultural industry and improves livelihoods in rural Uzbekistan.

The aim of the study is to review the agricultural sector of Uzbekistan with the purpose of identifying the major constraints to the development of the very same with special emphasis on the fruit and vegetables subsectors. In doing this, the objective is to put forward policy recommendations for the development of the sector. The study uses the agri-processing cluster which has core activity of production, processing and marketing of locally produced fruits and vegetables. Agro-clusters are the concentration of producers, agribusinesses and institutions that are engaged in the same agricultural or agro-industrial subsector, and interconnect and build value networks when addressing common challenges and pursuing common opportunities (Galvez-Nogales, 2010). Or as presented by Porter (1998) clusters are geographic concentrations of interconnected companies and 
institutions in a particular field. For instance, using an example of developing dairy cluster sector in Albania, Patushi ans Kume (2014) confirm that the cluster approach can be beneficial.

\section{Data and methodology}

The candidate regions for the clustering of agro-food processing special zones are Tashkent, Andijan and Samarkand. The selection in this study was done using the Potential Clustering Coefficient of AgroProcessing by Region and the Comparative Advantage in terms of production and processing. The coefficient of potential of clustering (CC) is calculated using the following equation (Romanov and Arushakov, 2008):

$$
C C=\mathrm{Cp} C s \text { Cproc } C p c p
$$

The core part of this method is to calculate the potential of clustering, where:

$C p$ - coefficient of production: defined as regional production divided to the average national production level;

Cs - coefficient of specialization: share of the region in total production of certain commodities divided by the regional share in the national gross agricultural output;

Cproc - coefficient of processing industry development: defined as the regional processing capacity divided by the average regional processing capacity;

Срср - coefficient of per capita production: defined as a share of the regional production in total national production divided by the share of regional population in total national population.

Based on the above equation, population density, surplus of labor forces of processing companies, shares in regional gross product, productive land area, and adequate supply of irrigation water are the main parameters used in the analysis. The database for this study was compiled using the national and regional statistical yearbooks (StatUz, 2015). The results show that, among all regions in Uzbekistan, Samarkand, Tashkent region, and the region of Fergana valley (Andijan, Namangan and Fergana) have the highest potential for developing fruit and vegetable clusters.

Out of them, three regions with the highest potential for production and processing of fruits and vegetables were selected as the target areas for clustering. In the next step, the coefficients of clustering potential were used as selection criteria. In this regard, the Samarkand region was selected for the pilot project-funding by the Korean government's Knowledge Sharing Program (KSP) project "Development of Agro-Processing Industry in Uzbekistan: Korea’s Experience and Knowledge Sharing”.

In the Samarkand region, the eastern districts, such as Bulungur, Urgut, Taylak, Jambay, Akdarya and Samarkand county, have the highest potential 
as cluster. These are the areas without cotton cultivation. These candidate districts have high density and share in the gross regional product. However, Urgut district produces ca. $80 \%$ of the national tobacco, with the most irrigated area being covered by tobacco and wheat. Only in its higher mountain areas rural households produce fruits like table and dried grapes, nuts, etc. Therefore, Urgut district was dropped from the list of candidates. The remaining districts were eligible candidates for clustering. To determine which district would be more suitable for pilot programs in agro-processing cluster, the study conducted an assessment of the potential of each district. In this regard, Bulungur and Jambay districts were selected, respectively, as pilot areas for implementation of agro-based clustering in tomato and apple production. SWOT analysis was conducted to analyze districts' potentials for fruit and vegetable production.

\section{Results}

The SWOT analysis of selected two districts shows that the current tomato supply chain is not stabile in Bulungur district (Table 2). As result, farmers, rural households and agro-processing companies can benefit from participating in Agro-clusters. The government encourages cluster-based programs to support farms. The agro-clustering approach has been considered particularly beneficial for farmers, as it allows producers to achieve economies of scale as well as share costs related to training, information access, certification and application of advanced technology.

The main problem of tomato production in Bulungur district is related to post-harvest activities since ca. 25-33\% of harvest is lost during the postharvest season. Problems of transportation, unstable contracts between producers and processors and a lack of storage facilities in rural areas contribute to the post-harvest losses. Post-harvest R\&D programs aimed at generating appropriate post-harvest technologies in Bulungur district are also in serious shortage. Furthermore, tomato is sold in local food markets in a fresh form after harvest. Local farmers and rural households bring their harvest directly in local food markets or sell to retailers in Bulungur and Samarkand. The marketing infrastructure in the district is underdeveloped as the centralized grading, packing and transit storage facilities, transportation and bulk storage facilities are underdeveloped or missing. Although most farmers and rural household in Bulungur district have enough knowledge in tomato production, in many cases they do not consider the consumers' needs for different tomato varieties. Hence, enhancing the entrepreneurial skills of farmers is required. On-farm sorting, pre-cooling, packing and storage facilities for tomatoes are essentially required for distant/export marketing.

The second district, Jambay, is selected as a pilot for agro-processing cluster of apples. Jambay has a favorable climatic condition for orchards and, 
especially, for apple. The district has also several manufacturing companies, including several companies engaged in food processing. There is also a relatively large number of skilled-labor with rich experience in apple production. Based on the state program, cotton cultivation in Jambay was abandoned and fruit and vegetable production was encouraged instead. The intensive apple gardens has become the governmental initiative as a part of the national program for establishing intensive orchards. There is a need to ensure adequate and stable production quantities of apples. In particular, the government can facilitate small-scale farms by integrating them into apple supply chain. Currently, small-scale farms contribute only a small share of total production of apples in Jambay. There is relatively sufficient infrastructure, especially storage facilities. However, these facilities are largely underutilized. Access of small-scale farms to these storage facilities would bring additional benefits. Furthermore, contract farming arrangements can be an option for linking smallholders and large producing companies or the owners of intensive gardens. 
Table 2: SWOT analysis of two district in Samarkand province.

\begin{tabular}{|c|c|c|}
\hline 㫐 & $\begin{array}{l}\text { STRENGTHS } \\
\text { Favorable climatic conditions: adequate irrigation water supply } \\
\text { and good soil quality for vegetable production. } \\
\text { Surplus of skilled labor, long traditions of growing tomato } \\
\text { Good logistic infrastructure: national/international roads, } \\
\text { railway. } \\
\text { Located in proximity to the Samarkand International airport. } \\
\text { Tremendous surplus of per capita production of tomato. } \\
\text { Big potential for exporting tomato. }\end{array}$ & $\begin{array}{l}\text { WEAKNESSES } \\
\text { Yields are lower: average tomato yield = } 21 \text { t/ha, it might increase up to } 32 \\
\text { t/ha. } \\
\text { Undeveloped modern market infrastructure: need of large storage facilities, } \\
\text { collection points, refrigerators, and packaging facilities. } \\
\text { High water losses: traditional surface irrigation system, water supply } \\
\text { problems to downstream area. Prices disparity: vegetables vs inputs. } \\
\text { Malfunctioning extension services in tomato supply chain. } \\
\text { Lack of modern mini-processing companies. } \\
\text { Lack of local projects/programs to attract domestic/foreign investment. }\end{array}$ \\
\hline 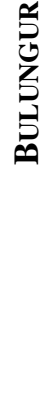 & $\begin{array}{l}\text { OPPORTUNITY } \\
\text { Local administration shows high enthusiasm in tomato cluster. } \\
\text { Tomato production area can be extended twice, without } \\
\text { decreasing area of other crops. Tomato production can be } \\
\text { expanded as a second crop after grain harvest (adequate for crop } \\
\text { rotation). } \\
\text { Potential for processing companies that functioned previously. } \\
\text { but and not in current operation. } \\
\text { Good connection with the Samarkand Agricultural University for } \\
\text { easy implementation of scientific know-how in production. }\end{array}$ & $\begin{array}{l}\text { THREATS } \\
\text { Lack of regional strategy to prepare for the risks and mitigation, district's } \\
\text { water supply depends on the neighboring country. } \\
\text { High competition and protectionism in world food markets; unregulated trade. } \\
\text { Lack of effective sea transport links to domestic and world food markets. }\end{array}$ \\
\hline
\end{tabular}




\begin{tabular}{|c|c|c|}
\hline 㫐 & $\begin{array}{l}\text { STRENGTHS } \\
\text { Favorable climatic condition for orchards, especially for apples. } \\
\text { Higher industrialization: five companies representing food } \\
\text { production sector. } \\
\text { State program (PA-1621, 27.09.2011): to enhance fruit and } \\
\text { vegetable production instead of cotton. } \\
\text { Surplus of skilled labor with local knowledge in apple } \\
\text { production. } \\
\text { Good logistic infrastructure, national/international roads, } \\
\text { railway. } \\
\text { Good connection to the Samarkand city and the Samarkand } \\
\text { International airport. } \\
\text { Surplus of per capita production of apples; increases in future }\end{array}$ & $\begin{array}{l}\text { WEAKNESSES } \\
\text { Lack modern market infrastructure. } \\
\text { Low implementation of modern water saving technology for orchards. } \\
\text { Malfunctioning extension services in production, processing, and marketing. } \\
\text { Lack of modern processing technologies. } \\
\text { Lack of local projects/programs to attract foreign investments. } \\
\text { Weak cooperation links between farmers and processors. } \\
\text { High cost of intensive orchards, imported from EU or other countries. } \\
\text { Absence of a local experimental research station. } \\
\text { Absence of grading system for apples for exports. }\end{array}$ \\
\hline 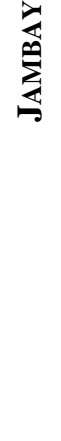 & $\begin{array}{l}\text { OPPORTUNITY } \\
\text { High interest of local administration in apple potential cluster. } \\
\text { Increase of high yield apple production areas without decreasing } \\
\text { area of other crops. } \\
\text { District location in the center of apple growing area of } \\
\text { Samarkand region. } \\
\text { Processing companies can access commodities from other } \\
\text { districts (Bulungur, Taylak, Samarkand, Akdarya etc). } \\
\text { Processing facilities are not operating in full capacity, e.g. } \\
\text { "Lazzat-Meva” uses only 7-8\% of full production capacity } \\
\text { (2012). This can be increased in future. }\end{array}$ & $\begin{array}{l}\text { THREATS } \\
\text { Lack of regional strategy for risks and mitigation. } \\
\text { High competition and protectionism in world food markets, unregulated trade. } \\
\text { Lack of effective sea transport links to domestic and world food markets. }\end{array}$ \\
\hline
\end{tabular}

Source: Base on the results of the Knowledge-sharing program (KSP) project “Clustering Agro-Processing Industry in Uzbekistan” Pilot Study for 2013. 
Similarly as in Bulungur, 12-15\% of apple production in Jambay is lost. There is a shortage of post-harvest technology due to a lack of sufficient $\mathrm{R} \& \mathrm{D}$ program in generating appropriate post-harvest techniques. Although post-harvest loss in apples is relatively lower than that of tomato in Bulungur, it is still significant and requires similar actions. The R\&D programs implemented at the national level could also consider apple production for establishing appropriate post-harvest technologies. The increased emphasis on intensive apple gardens provides an opportunity for utilizing the economies of scale and facilitating the services of quality control. Contract farming arrangements can also strengthen linkages between smallholders and bigger farms.

Apple production by smallholders in Jambay is mainly delivered in fresh form via retailers to local food markets in Samarkand city. Low quality apple produced mostly by rural households is used as livestock fodder. Apple harvested from these gardens during on-season periods are mainly stored for sales in fresh form during off-season times. Small share of the harvest considered of low quality for fresh sale undergoes some processing before being brought to markets. Apple production in the recently initiated intensive gardens has not yet reached sufficient levels for mass harvesting. Therefore, definitive scheme for promoting its marketing has not yet been designed. Since there is lack of a network of local markets, and poor access to market information, establishment of the national/regional information networking systems can bring additional gains. There is also a need to develop marketing centers at different levels to fill the existing gap in market infrastructure. Last but not least, promotion of strategic alliances with multinational companies and corporations would enhance the marketability of apple both domestically and internationally.

\section{Discussion and conclusion}

The strong seasonal pattern in the regional production shows that the domestic supplies have to meet a relatively stable domestic demand. Such price fluctuations for fresh fruits and vegetables indicate that development of local storage and processing facilities and off-season greenhouse production is required. Furthermore, promoting trade with other regions during the offseason can contribute to rice stabilization of these products.

Ensuring stable supply of vegetables and fruits requires a long-term approach to processing and distribution rather than a short-term perspective aimed at only increasing production. In particular, strengthening a stable production system coupled with capacity building of farmers is important for smooth implementation of agro-processing cluster. Stability of production does not only entail stability of quantity, but attention should also have to go to ensuring stability of product quality. In particular, quality standards can 
contribute to food safety, security and international trade (Larson et al., 2015).

An enhance of value-addition in the subsector and expansion of market access could be achieved through such interventions as promoting commercialization of production, identifying potential markets, promoting private sector participation in agro-processing and value addition, ensuring quality standards, promoting joint-marketing and distribution channels, adopting new varieties and production technologies, adopting efficient processing methods, developing high quality processed food for export markets, supporting processed food, expanding R\&D in processing, establishing specialized research institutes and realizing geographical advantages with better understanding of the characteristics of export markets.

Policies designed to promote the gainful incorporation of smallholders in national and global markets via general industrial support, or through programs designed to promote networked upgrading, can be crucial (Sikharulidze, 2011). Ensuring food safety and quality requires implementation measures of quality standards such as Good Agricultural Practices (GAP), Good Manufacturing Practices (GMP), Hazard Analysis and Critical Control Point (HACCP). In addition, provision of appropriate food safety and quality laboratories, along with trained scientists are crucial. Other interventions that need to be implemented are creating explicit standards covering domestic and international markets with appropriate inspection capacities; training all participants of horticulture value-chain; ensuring relevant and genuine supply of approved seed varieties. This optimal combination in promoting value chains and agro-clusters may provide a useful approach amongst others, to help achieve greater stability of the local production, market prices, efficient allocation of production resources as well as increase economic benefits and exports that without separating from social and environmental sustainability (Sini, 2014).

Human resource development is required at all levels that includes education and training of scientists, processors, extension agents, farmers, industrialists and marketing agents. All human resource programs should consist of long- and short-term activities. Promoting attitude of self-help, cooperation and hard work among farmers is also very important. Provision of extension services and training in post-harvest treatment and management to farmers, processors, researchers and government staffs from relevant ministries working in fruits and vegetables subsector is also beneficial.

This calls for concerted effort in availing key infrastructural services that includes investment in construction of infrastructure for postharvest handling, logistics, and marketing; production of cold chain infrastructure (refrigerated transport, cold rooms, low temperature sale stands); expansion of better roads, transportation, communication, and reliable electricity supplies. 


\section{References}

Cornia, G.A., McKinley, T., Spoor, M., Kotz, D.M., Saidova, G., Nasritdinkhodjaev, Z., Khaitov, A., Abduganieva, Y., Tukhanov, A. (2011) Growth and Poverty Reduction in Uzbekistan in the Next Decade. A Report Commissioned by the Poverty Group

Djanibekov, N., Rudenko, I., Lamers, J.P.A., Bobojonov, I. (2010) Pros and cons of cotton production in Uzbekistan, in P. Pinstrup-Andersen and F. Cheng, eds., Food Policy for Developing Countries: Food Production and Supply Policies, Cornell University Press, Ithaca.

Galvez-Nogales, E. (2010) Agro-based clusters in developing countries: staying competitive in a globalized economy. Food and Agriculture Organization of the United Nations (FAO). Rome.

Government of Japan (2006) Country Assistance Program for the Republic of Uzbekistan

Guadagni M., Raiser, M., Crole-Rees, A., Khidirov, D. (2005) Cotton taxation in Uzbekistan: Opportunities for reform. ECSSD Working Paper No 41. Europe and Central Asia Region, World Bank, Washington DC.

Hasanov Sh. and Ahmed, M.N. (2011) Agricultural efficiency under resource scarcity in Uzbekistan: A data envelopment analysis. Business and Economic Horizons. Vol.4, No.11.

Kim K.R., Hasanov Sh.(2013) Development of Agriculture and Marketing Structure in Uzbekistan for Agro- Processing of Fruits and Vegetables. Journal of Agricultural, Life and Environmental Sciences, 1-9, pp, Vol.25, No.2, July, 2013

Larson, D.F., Khidirov, D., Ramniceanu, I (2015) Uzbekistan Strengthening the Horticulture Value Chain. Uzbekistan Vision 2030 Background Paper Series , Washington, DC ; World Bank Group.

LEX.uz -An online national database of legislative acts of Republic of Uzbekistan

Mori-Clement Y., Bhaduri, A., Djanibekov, N. (2014) Food price fluctuations in Uzbekistan: Evidence from local markets in 2002-2010. In: Lamers, J.P.A., Khamzina, A., Rudenko, I., Vlek, P.L.G. (Eds.) Restructuring Land Allocation, Water Use and Agricultural Value Chains: Technologies, Policies and Practices for the Lower Amudarya Region. V\&R unipress, Bonn University Press, Goettingen, pp. 275-294.

Patushi, S., Kume, V. (2014) The development of clusters as a way to increase competitiveness of business: Case of milk processing industry in Tirana. European Scientific Journal 10 (13), 98-116.

Petrick, M., Djanibekov, N. (2016) Obstacles to crop diversification and cotton harvest mechanisation: Farm survey evidence from two contrasting districts in Uzbekistan. IAMO Discussion Paper No. 153, IAMO, Halle (Saale). 
Porter, M. (1998) On Competition. Boston: Harvard Business Review. Romanov, A. Arushakov, V. (2008) Formirovanie agropromishlennix klasterov v Rossii //APK -economika i upravlenie. № 3, p. 41-45 (in Russian).

Sikharulidze, D. (2011) The integration of small and medium-sized enterprises into global value chain. European Scientific Journal 20, 15-22.

Sini, P. (2014) Long and short term supply chain coexistence in the agricultural food market on different scakes: Oligopolies, local economies and the degree of liberalisation of the global market. European Scientific Journal 10 (4), 363-401.

StatUz (2015) An Outlook of The State Statistical Committee of Uzbekistan. World Bank (2010) Opportunities and Challenges for a Converging Agenda: Country Examples. 